\title{
Projekt studyjny Tłumaczenie sądowe (sprawozdanie)
}

DOI: http://dx.doi.org/10.12775/RP.2016.020

W roku akademickim 2015/2016 w Instytucie Filologii Germańskiej Uniwersytetu Wrocławskiego (IFG UWr) rusza nowy projekt studyjny dla tłumaczy sądowych. Wyrósł on z praktycznych potrzeb codzienności i jest adresowany do studentów specjalizacji translatorycznej. Pomysłodawcą i inicjatorem projektu jest Rafał Szubert, adiunkt w Zakładzie Języka Niemieckiego (IFG UWr), kierowanego przez Iwonę Bartoszewicz - Dyrektora Instytutu Filologii Germańskiej. Projekt jest realizowany w ramach specjalizacji translatorycznej, rozwijanej z inicjatywy Anny Małgorzewicz - Kierownika Pracowni Translatorycznej i Zakładu Glottodydaktyki w IFG UWr. Partnerem tej inicjatywy jest Prezes Wrocławskiego Sądu Okręgowego. Można zatem powiedzieć, że projekt rozwija się pod znakiem współpracy interdyscyplinarnej w obrębie Instytutu Filologii Germańskiej Uniwersytetu Wrocławskiego, wpisującej się w całej rozciągłości w jego tradycję.

Cele przedsięwzięcia sformułowane zostały na podstawie wyników badania przeprowadzonego przez Jerzego Żmudzkiego (Uniwersytet Marii Curie-Skłodowskiej w Lublinie), dokumentującego szczegółowo stan uniwersyteckiej dydaktyki przekładu w Polsce. Anna Małgorzewicz podkreśla, że wyniki wspomnianego wyżej badania pozwalają wątpić, czy uniwersytecka dydaktyka przekładu w Polsce uwzględnia w swych planach dydaktycznych i metodologicznych późniejszą działalność zawodową swych przyszłych absolwentów. Małgorzewicz zwraca przy tym uwagę, że określenie wyobrażenia o zawodzie powinno być kluczem do formułowania celów kształcenia (patrz: Małgorzewicz 2010: 22).

Sytuację taką należy próbować zmienić przez zastosowanie w dydaktyce idei projektowych, które mogą doprowadzić do systematycznego wyeliminowania deficytów w kompetencji kandydatów na tłumaczy słowa pisanego i tłumaczy słowa mówionego, których występowanie stwierdził w swoim badaniu Żmudzki.

$\mathrm{Na}$ etapie konstruowania celów i treści projektu studyjnego dla tłumaczy sądowych istotne było sformułowanie wartości kluczowych. Ich znaczenie wynikało $\mathrm{z}$ obserwacji i z doświadczenia pomysłodawcy i inicjatora pro- 
jektu, zdobywanych w obrębie uczelni macierzystej, a także poza nią. Jako pracownik naukowo-dydaktyczny IFG UWr jest on zarówno dydaktykiem przekładu, jak i badaczem aspektów tłumaczenia i translatoryki. Jest także tłumaczem przysięgłym języków niemieckiego i niderlandzkiego. Za wartość przewodnią uznano rolę języków obcych i specjalistycznych w kontekście rynku pracy oraz promocję współpracy interdyscyplinarnej środowiska filologów i prawników w Polsce. Celem tej współpracy ma być intensyfikacja działań zmierzających do wzrostu jakości wiedzy o sądzie jako obszarze działania kulturowego i językowego, a także promocja współpracy w zakresie opracowania i przygotowania materiałów dydaktycznych dotyczących tematyki projektu. Zagadnienie to było podejmowane przez autora projektu m.in. w referacie zatytułowanym Wie verständigt man sich vor Gericht? (Jak komunikuje się przed sądem?), wygłoszonym na konferencji językoznawczej „Kommunikation für Europa. Sprachkontakte - Sprachkultur - Sprachenlernen" (Komunikacja dla Europy. Kontakty językowe - kultura języka - nauka języków), która odbywała się w Pobierowie w dniach od 7 do 9 września 2003 roku, a także $\mathrm{w}$ artykule Uniwersytecka dydaktyka przekładu w Polsce i za granica, opublikowanym w „Roczniku Przekładoznawczym” (2008, t. 3/4). Wspomniane wartości i cele były także przedmiotem rozmów z Prezesem Sądu Okręgowego we Wrocławiu panem Marcinem Sosińskim, poprzedzających podpisanie umowy o realizacji projektu studyjnego. Cele te zostały ujęte $\mathrm{w}$ tytule umowy: Umowa dotycząca zapoznania się z organizacją i zasadami funkcjonowania sądu oraz autentycznymi sytuacjami związanymi z pracą tłumacza sądowego. Umowę podpisały w roku akademickim 2014/2015 Wydział Filologiczny Uniwersytetu Wrocławskiego i Sąd Okręgowy we Wrocławiu. Na jej podstawie studenci specjalizacji przekładoznawczej (translatorycznej) Instytutu Filologii Germańskiej Uniwersytetu Wrocławskiego będą mogli uczestniczyć $\mathrm{w}$ charakterze publiczności w procesie sądowym $\mathrm{z}$ udziałem tłumacza lub bez niego. Umowa obejmuje również uczestnictwo w spotkaniu z sędzią rozpoznającym sprawę i rozmowę z nim o przebiegu obejrzanego procesu sądowego.

Decyzja o wyborze przekładu sądowego (ustnego i pisemnego) jako przedmiotu projektu studyjnego wyniknęła z przekonania autora projektu i autorytetów, których opinii zasięgał on przed sformułowaniem celów całego przedsięwzięcia, że zapotrzebowanie na tłumaczenia prawnicze, $w$ tym tłumaczenia sądowe, wzrasta wraz z rozwojem rynku międzynarodowego, czego konsekwencją jest rosnący popyt na usługi tłumaczy dysponujących kompetencjami w zakresie sądownictwa i administracji. To przekonanie doprowadziło do decyzji o poszerzeniu dydaktyki przekładu o nowy składnik, 
czyli o tłumaczenie sądowe. W wyniku tej modyfikacji studenci specjalizacji translatorycznej w IFG UWr mają w semestrze zimowym roku akademickiego 2015/2016 30 godzin ćwiczeń praktycznych w zakresie tłumaczenia symultanicznego i konsekutywnego, a w semestrze letnim 30 godzin ćwiczeń z tłumaczenia sądowego. Zmiany w polskim prawie karnym, obowiązujące od 1 lipca 2015 roku, wywołały potrzebę modyfikacji części materiałów dydaktycznych do nauki przekładu pisemnego. Innego niż dotychczas obowiązujący doboru tekstów do ćwiczeń wymaga na przykład założenie, że czynności dowodowe będą ciążý teraz na stronach postępowania, a jedynie wyjątkowo wykorzystywana będzie inicjatywa dowodowa sądu. W nowym modelu postępowania sądowego sąd powinien odgrywać rolę arbitra, który po przeprowadzeniu przez strony dowodów wyda rozstrzygnięcie. Kolejną modyfikacją, która winna zostać uwzględniona w materiałach dydaktycznych, jest zwiększenie stosowania trybów konsensualnych, to znaczy na przykład zawierania porozumień między prokuratorem a oskarżonym, przedkładanych do akceptacji sądu. W razie ich przyjęcia proces przed sądem nie będzie konieczny. Konsekwencją tej modyfikacji może być na przykład zmiana w częstotliwości pojawiania się pewnych rodzajów tekstów, jak choćby wniosek o skazanie bez rozprawy (Antrag auf Erlass eines Strafbefehls ohne Hauptverhandlung) czy wniosek o dobrowolne poddanie się karze (Antrag auf Zustimmung zur freiwilligen Unterwerfung unter die Verantwortlichkeit). Z przeprowadzania niniejszego projektu będą sporządzane regularnie sprawozdania. Ich znaczenie polega przede wszystkim na weryfikacji kierunku i sposobu wykonywanych działań w celu dbałości o ich najwyższą jakość.

Rafał Szubert (Uniwersytet Wrocławski)

\section{Literatura}

Małgorzewicz, A., 2010, „Auf dem Weg zu einem Modell der Translationsdidaktik", [w:] Glottodidactica, Vol. XXXVI, Poznań, s. 21-32.

Szubert, R., 2004, „Wie verständigt man sich vor Gericht?”, [w:] Kommunikation für Europa. Sprachkontakte-Sprachkultur-Sprachlernen, J. Schiewe, R. Lipczuk, W. Westphal (red.), Szczecin, s. 165-171.

Szubert, R., 2008, „Uniwersytecka dydaktyka przekładu w Polsce i za granicą”, [w:] Rocznik Przekładoznawczy. Studia nad teoria, praktyka i dydaktyka przekładu, t. 3/4, s. 315-329. 
Żmudzki, J., 1998, „Zum Stand der Translatorik in Polen”, [w:] Deutsch und Auslandsgermanistik in Mitteleuropa. Geschichte - Stand - Ausblicke, F. Grucza, T. Namowicz, J. Wiktorowicz, L. Kolago (red.), Warszawa, s. 487-498.

(c) $)(1)$ 